\title{
Effect of Aphid Behavior on Efficiency of Transmission of Soybean mosaic virus by the Soybean-Colonizing Aphid, Aphis glycines
}

\author{
R. Y. Wang and S. A. Ghabrial, Department of Plant Pathology, University of Kentucky, Lexington 40546
}

\begin{abstract}
Wang, R. Y., and Ghabrial, S. A. 2002. Effect of aphid behavior on efficiency of transmission of Soybean mosaic virus by the soybean-colonizing aphid, Aphis glycines. Plant Dis. 86:12601264.

The soybean aphid (Aphis glycines) was a poor vector ( $0.83 \%$ transmission) when the aphids were allowed overnight acquisition feed on Soybean mosaic virus (SMV)-infected soybean leaves. However, A. glycines was shown to be a very efficient vector (34.72\% transmission) when individual aphids were allowed a 1-min acquisition probe on the same infected leaves used for the feeding treatment. Similar results were obtained with Myzus persicae and tobacco in transmission experiments of the potyviruses Tobacco etch virus (feeding: 1.36\%; probing: 45.5\%) and Tobacco vein mottling virus (feeding: 2.0\%; probing: $47.5 \%$ ). A reverse transcription-polymerase chain reaction (RT-PCR) assay was developed to detect SMV in single soybean aphids using a pair of primers designed to amplify a 469-bp PCR fragment in the coding region of SMV coat protein. In contrast to the low transmission rate obtained with the soybean aphids that acquired virus through overnight feeding, RT-PCR detected SMV in 100\% of these aphids. Interestingly, the rate of SMV detection by RT-PCR in aphids that were allowed a 1-min acquisition probe $(31.67 \%)$ coincided with percent transmission $(34.72 \%)$. The practical application of RT-PCR in detecting nonpersistently transmitted viruses and its implications for virus epidemiology are discussed.
\end{abstract}

Soybean mosaic virus (SMV) occurs in all soybean-producing regions worldwide. Plants grown from SMV-infected soybean seeds provide the primary inoculum source. Secondary virus spread within and between fields is mediated by several aphid species, with transmission occurring in a nonpersistent manner $(2,12,15,16,29,41)$. SMV can significantly reduce soybean yields, and yield losses as high as 50\% have been reported (17). In addition, SMV interacts synergistically with the comovirus Bean pod mottle virus (BPMV) with a drastic reduction of yield and seed quality $(1,3,26)$. Increased incidence of mixed infections with SMV and BPMV is presently of major concern in view of the recent outbreak of BPMV in the northcentral and southeastern states (10).

The soybean aphid (Aphis glycines Matsumura), a native of Asia, was first observed in North America in Wisconsin during the summer of 2000. By the end of the 2000 growing season, it was detected in Illinois, Indiana, Iowa, Kentucky, Michigan, Minnesota, Missouri, Ohio, and West Virginia. In addition to the direct damage caused by aphid feeding, the soybean aphid is capable of transmitting a

Corresponding author: S. A. Ghabrial

E-mail: saghab00@uky.edu

Accepted for publication 2 July 2002.

Publication no. D-2002-0822-02R

(c) 2002 The American Phytopathological Society number of plant viruses known to naturally infect soybean in the United States, including SMV, Bean yellow mosaic virus, Peanut mottle virus, Alfalfa mosaic virus (AMV), and Peanut stunt virus. The transmission of these viruses in soybean fields by the soybean aphid, however, has not been documented (North Central Pest Alert Factsheet: Soybean Aphid, Aphis glycines; on-line publication). In a recent laboratory study, Hill et al. (14) showed that A. glycines efficiently transmitted an isolate of SMV endemic in Iowa, using 3 to 10 aphids per plant, whereas AMV was less efficiently transmitted by the soybean aphid in a similar experiment.

The recent introduction of the soybean aphid in the United States raises serious questions in regard to the spread of persistently and nonpersistently transmitted viruses in soybean fields. To address such questions requires the availability of sensitive methods for detecting viruliferous soybean aphids. The polymerase chain reaction (PCR) is a very sensitive and specific technique, and reverse transcription PCR (RT-PCR) has been widely used for the detection of RNA plant viruses that occur in extremely low concentrations. Recent studies have shown that viruses can be detected in individual viruliferous aphids using PCR (19) and RT-PCR $(4,11,22,30-35)$. The objectives of this study were to develop an RT-PCR assay for detecting SMV in single viruliferous soybean aphids and to assess its usefulness in estimating the impact of A. glycines on the spread of SMV in future epidemiologi- cal studies. The potential risk of the recent introduction of A. glycines on the spread of nonpersistently and persistently transmitted viruses in soybeans in the United States is discussed.

\section{MATERIALS AND METHODS}

Viruses. A Kentucky isolate of SMV strain G-2 (5) was used in most experiments. The source and properties of the Tobacco etch virus (TEV) and Tobacco vein mottling virus (TVMV) isolates used have been previously described (38). SMV was maintained in soybean cv. Essex; TEV and TVMV were maintained in tobacco (Nicotiana tabacum cv. Ky-14).

Aphids and transmission tests. A colony of $A$. glycines was supplied by Grayson Brown, University of Kentucky. A. glycines was reared on healthy soybean plants, and Myzus persicae (Sulzer) was reared and handled as previously described (25). Late instar apterae were used in all tests. For overnight acquisition feed tests, aphids were kept on a detached virusinfected leaf in a petri dish with a moistened filter paper overnight. The youngest fully expanded trifoliolate leaves from SMV-infected soybean plants at the V-5 stage (8) or the youngest leaf from TEV- or TVMV-infected tobacco plants in the fourto five-leaf stage were used. In all cases, the source leaves were showing typical mosaic/mottling symptoms of the respective viruses. Only aphids that were actively feeding on the leaf at sampling time were used for RT-PCR or transmission tests. For the 1-min acquisition access tests, aphids were collected and kept in glass vials for 2 to $3 \mathrm{~h}$ of preacquisition fasting. Starved aphids were then placed on the same virusinfected leaf after removing all of the aphids that were allowed to feed overnight. The starved aphids were allowed a 1-min acquisition probe that was observed under a dissecting microscope. Afterward, they were tested by RT-PCR or assayed in transmission tests. For transmission tests, aphids were transferred to test plants, soybean seedlings at the V-1 stage (8), or tobacco seedlings at the two-leaf stage (one aphid per plant) and allowed to remain on the test plants overnight. The plants were then sprayed with an insecticide and placed in a growth room for 2 to 3 weeks for symptom development. A. glycines was used for SMV transmission tests, and $M$. persicae was used for TEV and TVMV transmission tests.

RNA extraction from SMV-infected plants. Two methods were used to extract 
total RNA from healthy and SMV-infected leaves: (i) A leaf disk (approximately 10 $\mathrm{mm}$ in diameter) was ground in liquid nitrogen in a mortar with a pestle and then mixed with $300 \mu \mathrm{l}$ of extraction buffer $(0.1$ $\mathrm{M}$ glycine, $0.1 \mathrm{M} \mathrm{NaCl}, 0.01 \mathrm{M}$ EDTA, $1 \%$ sodium dodecyl sulfate (SDS), $1 \%$ mercaptoethanol, $\mathrm{pH}$ 9.0). The homogenate was first extracted with phenol followed by phenol/chloroform, and then the total RNA was precipitated with ethanol and resuspended in $50 \mu \mathrm{l}$ of sterile $\mathrm{H}_{2} \mathrm{O}$; and (ii) The extraction was performed using a commercial RNeasy Mini Kit (Qiagen Inc., Valencia, CA). A leaf disk was ground in liquid nitrogen in a mortar with a pestle and then mixed with $450 \mu \mathrm{l}$ of RLT lysis buffer (RNeasy Mini Kit, Qiagen). The homogenate was transferred into a $1.5-\mathrm{ml}$ microfuge tube and centrifuged for $10 \mathrm{~min}$ at $12,000 \times g$. The supernatant was further processed according to the manufacturer's instructions. The final total RNA was suspended in $50 \mu$ of sterile $\mathrm{H}_{2} \mathrm{O}$.

Extraction of viral RNA from individual viruliferous aphids. We tested several methods for extraction of total RNA from individual viruliferous aphids, including the procedures developed by Lopez-Moya et al. (19) and Singh et al. $(32,33)$, and those described above for SMV-infected plants. Only extraction with the RNeasy Mini Kit (Qiagen) produced consistent and reliable results. Individual aphids were placed into a chilled mortar containing liquid nitrogen. As soon as the liquid nitrogen evaporated, the frozen aphid was ground with a pestle, and $200 \mu \mathrm{l}$ of RLT lysis buffer (RNeasy Mini Kit, Qiagen) was added into the mortar, and the homogenate was further mixed with a pestle. The homogenate was transferred into a $1.5-\mathrm{ml}$ microfuge tube, and the mortar was rinsed twice with $200 \mu \mathrm{l}$ of RLT buffer each time. The combined homogenate and rinse mixture (a total of $600 \mu \mathrm{l}$ in RLT buffer) were then centrifuged for $5 \mathrm{~min}$ at $12,000 \times g$. The supernatant was further processed according to the manufacturer's instructions, and the final total RNA was suspended in $25 \mu$ of $\mathrm{H}_{2} \mathrm{O}$.

RT-PCR. A pair of primers, a forward primer (SMV-CPf; 5'-CAAGCAGCAAAG ATGTAAATG-3') and a reverse primer (SMV-CPr; 5'-GTCCATATCTAGGCATA TACG- $3^{\prime}$ ), was designed to prime the amplification of a conserved region (a fragment of $469 \mathrm{bp}$ ) in the coding region of SMV coat protein $(\mathrm{CP})$. The sequences of the forward and reverse primers correspond to nucleotide positions 8615 to 8635 and 9061 to 9081, respectively, in the sequence of SMV strain G-2 (GenBank accession no. S42280). The following SMV strains (GenBank accession numbers in parentheses) have identical sequences to strain G-2 in the regions covered by the two primers: A-15 (AF242844), ChS (AF200581), G-1 (AF200560), G-3 (AF200563), G-5 (AF200566), G-6
(AF242845), G-7 (AF241739), IL-1 (AF200581), N (NC002634), VA-1 (AF200578), and VA-2 (AF200584).

Two methods were used to perform RTPCR for SMV-infected plants and individual viruliferous aphids. The first was a two-step RT-PCR. For the RT reaction, $3 \mu \mathrm{l}$ of total RNA from plants or $11 \mu \mathrm{l}$ of total RNA from aphids was denatured for $2 \mathrm{~min}$ at $72^{\circ} \mathrm{C}$ and immediately chilled on ice. The samples were added to $17 \mu \mathrm{l}$ of reaction mixture $(4 \mu \mathrm{l}$ of $5 \times$ first-strand buffer, $1 \mu \mathrm{l}$ of $0.1 \mathrm{M}$ dithiothreitol [DTT], $0.5 \mu \mathrm{l}$ of RNasin [40 $\mathrm{u} / \mu \mathrm{l}$; Promega, Madison, WI], $1 \mu \mathrm{l}$ of dNTPs [10 mM each], $2 \mu \mathrm{l}$ of reverse primer [10 pmoles/ $\mu \mathrm{l}], 0.5 \mu \mathrm{l}$ of SuperScript II [200 u/ $\mu \mathrm{l}$; GIBCO BRL, Gaithersburg, MD], and $8 \mu \mathrm{l}$ of $\mathrm{H}_{2} \mathrm{O}$ [no $\mathrm{H}_{2} \mathrm{O}$ for aphid samples]) and incubated for $1 \mathrm{~h}$ at $42^{\circ} \mathrm{C}$. Five microliters of cDNA (20 $\mu \mathrm{l}$ cDNA for the aphid samples) were added to $45 \mu$ of PCR reaction mixture (5 $\mu \mathrm{l}$ of $10 \times$ PCR buffer containing $25 \mathrm{mM}$ $\mathrm{MgCl}_{2}, 1 \mu \mathrm{l}$ of dNTPs [10 mM each], $3 \mu \mathrm{l}$ of forward primer [10 pmoles/ $\mu \mathrm{l}], 2.5 \mu \mathrm{l}$ of reverse primer [10 pmoles/ $\mu \mathrm{l}], 0.25 \mu \mathrm{l}$ of PCR enzyme [Deep Vent DNA polymerase $2 \mathrm{u} / \mu \mathrm{l}$; New England BioLabs, Beverly, MA], and $33.25 \mu \mathrm{l}$ of $\mathrm{H}_{2} \mathrm{O}$ [18.25 $\mu \mathrm{l}$ of $\mathrm{H}_{2} \mathrm{O}$ for the aphid samples]). Thermal cycling conditions were: $94^{\circ} \mathrm{C}$ for $2 \mathrm{~min}$, 35 cycles (40 cycles for aphid samples) of $94^{\circ} \mathrm{C}$ for $1 \mathrm{~min}, 55^{\circ} \mathrm{C}$ for $1 \mathrm{~min}, 72^{\circ} \mathrm{C}$ for 2 min, and a final extension at $72^{\circ} \mathrm{C}$ for 10 min. Five microliters of PCR products were analyzed by agarose gel electrophoresis in $1.2 \%$ gels and stained with ethidium bromide.

The second method was a one-step RTPCR with a commercial kit (SuperScript One-Step RT-PCR with PLATINUM Taq, Invitrogen Life Technologies). Three microliters (20 $\mu$ f for aphid samples) of total RNA was added to $47 \mu \mathrm{l}(30 \mu \mathrm{l}$ for aphids) of reaction mixture $(25 \mu \mathrm{l}$ of $2 \times$ Reaction Mix, $2 \mu \mathrm{l}$ of forward primer [10 pmoles/ $\mu \mathrm{l}], 2 \mu \mathrm{l}$ of reverse primer [10 pmoles/ $\mu \mathrm{l}], 1 \mu \mathrm{l}$ of RT/PLATINUM Taq Mix, and $17 \mu \mathrm{l}$ of $\mathrm{H}_{2} \mathrm{O}$ [no $\mathrm{H}_{2} \mathrm{O}$ for aphid samples]). Thermal cycling conditions were: 1 cycle of $50^{\circ} \mathrm{C}$ for $30 \mathrm{~min}, 1$ cycle of $94^{\circ} \mathrm{C}$ for $2 \mathrm{~min}$, followed by 35 cycles

Table 1. Effect of acquisition access period on efficiency of transmission by aphids of nonpersistently transmitted viruses ${ }^{\mathrm{a}}$

\begin{tabular}{|c|c|c|c|c|c|c|}
\hline \multirow[b]{2}{*}{ Virus } & \multirow[b]{2}{*}{ Treatment $^{b}$} & \multicolumn{4}{|c|}{ Number of infected plants/total tested ${ }^{c}$} & \multirow{2}{*}{$\begin{array}{c}\text { Transmission } \\
(\%)\end{array}$} \\
\hline & & Test 1 & Test 2 & Test 3 & Total & \\
\hline \multirow[t]{2}{*}{ SMV } & Feeding & $1 / 43$ & $0 / 47$ & $1 / 152$ & $2 / 242$ & 0.83 \\
\hline & Probing & $35 / 85$ & $48 / 136$ & $42 / 139$ & $125 / 360$ & 34.72 \\
\hline \multirow[t]{2}{*}{ TEV } & Feeding & $1 / 110$ & $2 / 110$ & $2 / 100$ & $5 / 320$ & 1.56 \\
\hline & Probing & $42 / 100$ & $49 / 100$ & $43 / 100$ & $134 / 300$ & 44.67 \\
\hline \multirow[t]{2}{*}{ TVMV } & Feeding & $2 / 100$ & $2 / 100$ & $1 / 100$ & $5 / 300$ & 1.67 \\
\hline & Probing & $45 / 100$ & $46 / 100$ & $46 / 100$ & $137 / 300$ & 45.67 \\
\hline
\end{tabular}

a SMV = Soybean mosaic virus, TEV = Tobacco etch virus, TVMV = Tobacco vein mottling virus Aphis glycines was used for SMV transmission and Myzus persicae was used for TEV and TVMV transmission.

${ }^{\mathrm{b}}$ Feeding: aphids were allowed overnight feeding access on virus-infected leaves; probing: aphids were observed with a dissecting microscope to probe the virus-infected leaves for $1 \mathrm{~min}$.

${ }^{c}$ Aphids were transferred to test plants (one aphid per plant) and kept on the test plants overnight. 


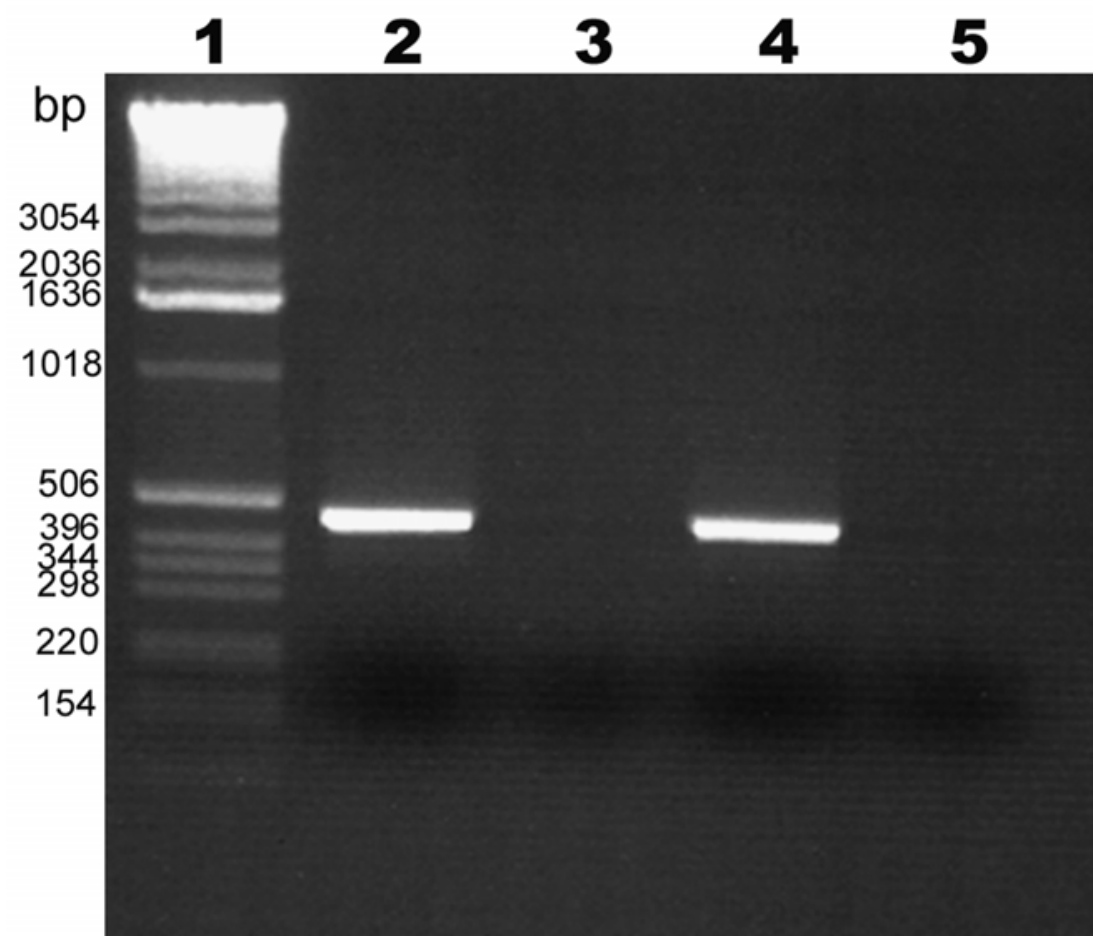

Fig. 1. Reverse transcription-polymerase chain reaction (RT-PCR) analysis of total RNA from Soybean mosaic virus (SMV)-infected plants or individual viruliferous Aphis glycines. The primers used for RT-PCR (SMV-CPf and SMV-CPr) are specific for SMV coat protein coding sequence and are predicted to prime the amplification of a product $469 \mathrm{bp}$ in size. The RT-PCR products generated with total RNA samples from SMV-infected and healthy leaves (lanes 2 and 3, respectively) and from single viruliferous and nonviruliferous control aphids (lanes 4 and 5, respectively) were subjected to electrophoresis on 1\% agarose and stained with ethidium bromide. Lane 1: $1 \mathrm{~kb}$ DNA ladder (Gibco BRL, Gaithersburg, MD).



Fig. 2. Reverse transcription-polymerase chain reaction (RT-PCR) analysis of total RNA from Soybean mosaic virus (SMV)-infected soybean plants. The primers used for RT-PCR (SMV-CPf and SMV-CPr) are specific for SMV coat protein coding sequence and are predicted to prime the amplification of a product $469 \mathrm{bp}$ in size. Lane 1: $1 \mathrm{~kb}$ DNA ladder (GIBCO BRL, Gaithersburg, MD); lane 2: AvaII digestion pattern of the SMV RT-PCR product showing the predicted two fragments of 112 and $357 \mathrm{bp}$; lane 3: HindIII digestion pattern of the SMV RT-PCR product showing the predicted two fragments of 53 and $416 \mathrm{bp}$; lane 4: undigested RT-PCR product. The RT-PCR and digestion products were visualized by $1 \%$ agarose gel electrophoresis and ethidium bromide staining.
SMV detection in individual $A$. glycines following feeding/probing. Although A. glycines was a poor vector when the aphids were allowed overnight acquisition feed on SMV-infected soybean $(0.83 \%$, Table 1$)$, the virus was detected by RT-PCR in $100 \%$ of these aphids (Table 2). In contrast, SMV was detected by RT-PCR in only $31.67 \%$ of the aphids after a 1 -min acquisition probe on SMV-infected leaves (Table 2). In the latter case, the transmission rate $(34.72 \%$, Table 1$)$ was comparable to the SMV detection rate $(31.67 \%$, Table 2). The intensity of the RT-PCR product, as viewed in stained gels, varied somewhat among individual aphids in the same treatment (overnight or 1-min acquisition access), and there were no apparent differences in band intensity between the two treatments (Fig. 3).

\section{DISCUSSION}

Although SMV is widespread on soybeans in the United States $(17,27)$, the magnitude of yield losses is not as great as that reported from some Asian countries where A. glycines occurs naturally $(28,39,41)$. The direct losses due to feeding by the colonizing soybean aphids could be a factor in this regard. Ever since A. glycines was found in the United States in the summer of 2000, many laboratories in the major soybean growing regions have become actively engaged in evaluating its impact on soybean production (North Central Soybean Research Program annual meeting, 2001; John Hill, personal communication). In a preliminary survey of SMV incidence in soybean fields in 23 counties in Kentucky, conducted in August 2001, SMV was detected in only $0.8 \%$ of the leaf samples collected (over 6,000 samples were examined). In contrast, BPMV, vectored by bean leaf beetles, was detected in $17.6 \%$ of the samples. Thus, SMV incidence was limited in the soybean fields surveyed even though A. glycines was widely present in those fields (S. A. Ghabrial and D. E. Hershman, unpublished).

A. glycines has a complex life cycle that utilizes two very different types of host plants $(37,40)$. It survives from fall to spring as overwintering eggs on buckthorn (Rhamnus spp.; 37). In the spring, it migrates from buckthorn in search of soybean, where it feeds throughout the growing season. During the soybean growing season, a series of wingless generations develop in the soybean fields. When the aphid population density increases on a given plant, a winged generation is produced that disperses in search of other soybean plants (20). In the fall, the aphids migrate back to Rhamnus spp. and produce eggs that overwinter. Thus far, two exotic Rhamnus spp. ( $R$. davurica and $R$. cathartica) have been shown to be acceptable winter hosts for A. glycines in North America (North Central Pest Alert Factsheet: 
Soybean Aphid, Aphis glycines; on-line publication). Other native or exotic Rhamnus spp. that could serve as winter hosts for the soybean aphids may still be found in the United States.

As aphid-borne, long-distance movement of SMV is not known to occur in nature (17), it is assumed that immigrant alate aphids from buckthorn are not infective. Because SMV has a very narrow host range, infected seedlings from infected soybean seeds provide the only known primary virus source, and aphids are responsible for secondary spread of SMV in soybean fields $(2,9,15,16,29,41)$. Based on our experiments comparing overnight versus 1-min acquisition access, it is quite clear that aphid behavior will dictate transmission efficiency. Thus, conditions that allow sustained feeding by the colonizing A. glycines would render them inefficient vectors of nonpersistently transmitted viruses. The low transmission efficiency, however, may be offset by the large population size that could potentially occur in the field. Although unproven, it is possible that initial flights of winged colonizers would involve multiple plant-toplant hopping, resulting in more efficient spread of the virus.

It is well known that probing plays a major role in the spread of nonpersistently transmitted viruses in the fields $(7,23)$, and it does not matter whether the aphid vector can colonize soybean or not if the aphid behavior is taken into account. When an aphid lands on a plant following a short or long distance flight, it will initially probe the epidermal cells to determine whether the plant is a suitable host rather than begin feeding upon arrival $(7,23,36,42)$. It is these brief probes (usually less than $30 \mathrm{~s}$ ) used to test the potential food source that are also optimal for acquisition or inoculation of nonpersistently transmitted viruses.

Our results indicate that $A$. glycines can be a very efficient vector of SMV if the aphid briefly probes the infected soybean plant prior to moving to a healthy plant. Our finding that the rate of detection of SMV by RT-PCR in aphids that were allowed a 1-min acquisition probe is similar to the transmission rate is of considerable interest. It is tempting to surmise that an assessment by RT-PCR of the percentage of virus-carrying, noncolonizing aphid vectors collected from traps may serve as an indicator of the extent of incidence of nonpersistently transmitted viruses in a certain soybean field or in a specific location where the traps are set up. A. glycines, which colonizes soybean, should not be included in such an assessment, as this will lead to an overestimate of virus incidence (Table 2). Because it is not possible to distinguish transient soybean aphids caught in traps from those that were colonizers but have taken flight, RT-PCR testing of individual $A$. glycines should be done separately and the results evaluated in compari- son with virus incidence in the fields where the traps are set up. Obviously, these proposals need to be tested in several locations over a number of growing seasons prior to their implementation.

RT-PCR is an extremely sensitive technique and has been widely used in the detection of plant viruses that occur at rather low concentrations in their host plants or that are unevenly distributed in the plants (13). It has also been used to detect several persistently and nonpersistently transmitted viruses in single aphids $(4,22,30,32,33,35)$. All these studies emphasized that virus detection in aphids by RT-PCR has a potential application in monitoring virus incidence in the field. In a study to estimate the minimal number of virions required for aphid transmission, it was reported that aphids need only to acquire approximately 10 to 100 virus particles to transmit viruses in a nonpersistent manner (24). Using autoradiographic microscopy in the study of potyvirus transmission by aphids, Wang et al. (38) concluded that only those virions retained within aphid stylets are primarily involved in aphid transmission. Later, Martin et al. (21) further defined that only the tip of the stylets $(2$ to $8 \mu \mathrm{m})$, where the food canal and salivary canal fuse, play an important role in virus inoculation by aphids. For

Table 2. Detection of Soybean mosaic virus by reverse transcription-polymerase chain reaction in individual Aphis glycines following virus acquisition by feeding or probing ${ }^{\mathrm{a}}$

\begin{tabular}{lccccc}
\hline & \multicolumn{3}{c}{ Number of virus-carrying aphids/total tested } & \\
\cline { 2 - 4 } Treatment & Test $\mathbf{1}$ & Test 2 & Test 3 & Total & Detection (\%) \\
\hline Feeding & $20 / 20$ & $12 / 12$ & $12 / 12$ & $44 / 44$ & 100 \\
Probing & $4 / 12$ & $7 / 24$ & $8 / 24$ & $19 / 60$ & 31.67 \\
\hline
\end{tabular}

a Feeding: aphids were allowed overnight feeding access on virus-infected leaves; probing: aphids were observed with a dissecting microscope to probe the virus-infected leaves for $1 \mathrm{~min}$.
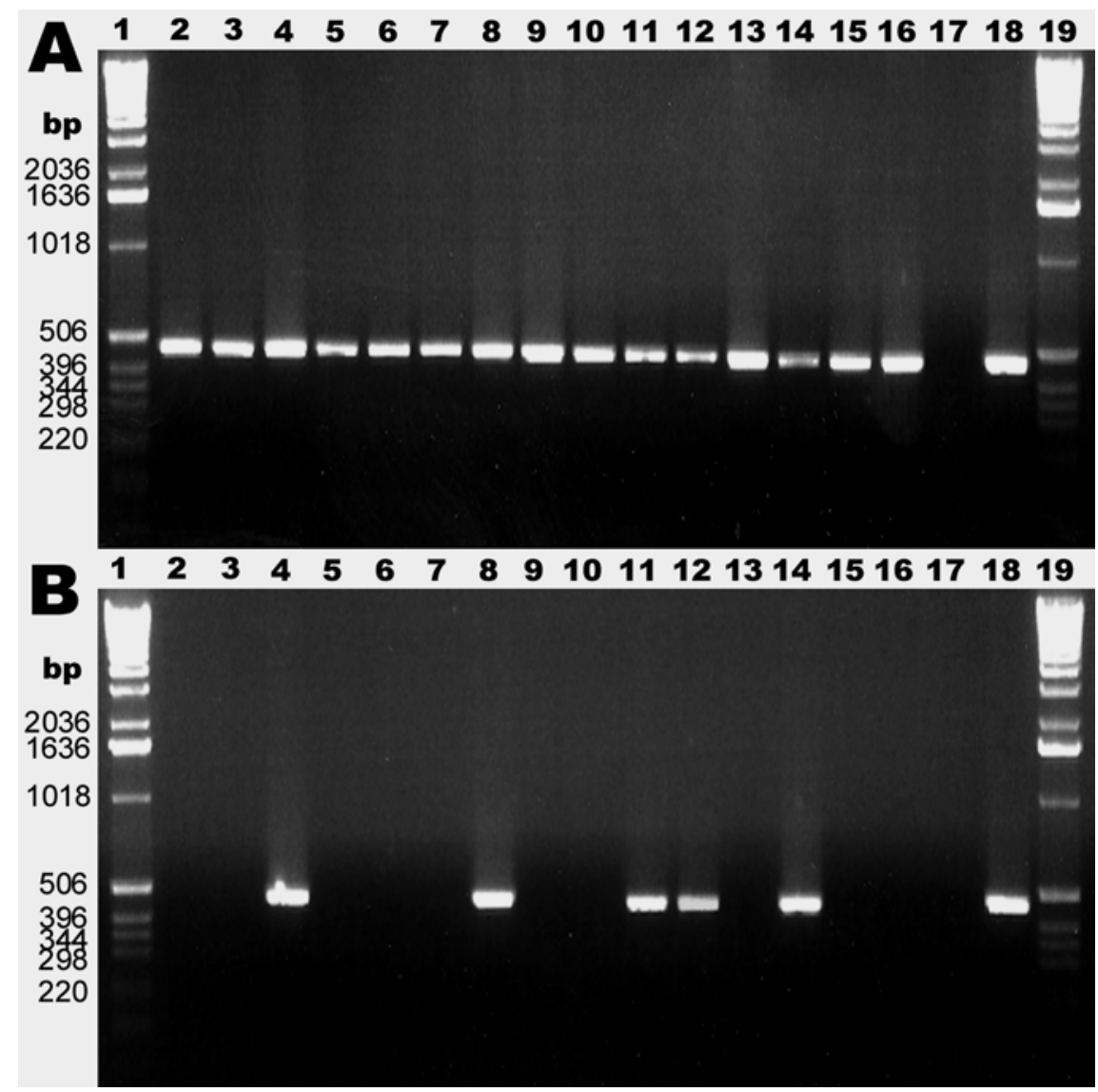

Fig. 3. Agarose gel electrophoresis of reverse transcription-polymerase chain reaction products generated with total RNA from individual aphids after different acquisition access periods to SMVinfected soybean leaves. A, Aphids that were allowed overnight acquisition feed. Lanes 1 and 19: 1kb DNA ladder (GIBCO BRL, Gaithersburg, MD); lanes 2 to 16: samples from aphids with overnight acquisition feed; lane 17: a sample from nonviruliferous aphid; lane 18: a sample from a Soybean mosaic virus (SMV)-infected leaf used for overnight acquisition feed. B, Aphids that were allowed a 1-min acquisition probe. Lanes 1 and 19: 1-kb DNA ladder (GIBCO BRL); lanes 2 to 16: samples from aphids with 1-min acquisition probe; lane 17: a sample from a nonviruliferous aphid; lane 18: a sample from an SMV-infected leaf used for the 1-min acquisition access. 
efficiency purposes, total RNA from whole aphids rather than from stylets or tips of stylets was tested in our RT-PCR assays. The results from such assays, therefore, could only predict the presence in the field of the viral pathogen and its potentially efficient vector, but would not foretell the rate of transmission or the level of virus spread in the field.

The impact of the introduction of A. glycines into the United States on soybean production is still unclear. The major economically important, aphid-vectored viruses that infect soybeans are largely nonpersistently transmitted viruses. Our study has shown that $A$. glycines can be a very efficient vector for such viruses if the aphid briefly probes the infected soybean plant prior to moving to a healthy plant. Thus, factors that influence population density, emergence of winged generations, and feeding habits of the individual winged aphids are predicted to have an impact on virus spread by $A$. glycines. The fact that the soybean aphid is also known in Asia to efficiently transmit some luteoviruses in a persistent manner (18) represents a potential risk, since a number of luteoviruses, e.g., Soybean dwarf virus and Bean leafroll virus, are known to be endemic in forage legumes in many of the soybean growing regions in the United States (6). The use of RT-PCR for the detection of targeted persistently and nonpersistently transmitted viruses $(4,11,30,33$, this study) in infected soybean plants as well as in single aphids collected from suction traps should provide a reliable and highly sensitive means for monitoring virus incidence in soybean fields infested with the soybean aphid.

\section{ACKNOWLEDGMENTS}

We thank Grayson Brown and Thomas Pirone for critical reading of the manuscript. This research was supported by CSREES Agreement No. 2001-34103-10535 from the U.S. Department of Agriculture. This paper (No. 02-12-59) is published with the approval of the Director of the Kentucky Agricultural Experiment Station.

\section{LITERATURE CITED}

1. Anjos, J. R., Jarlfors, U., and Ghabrial, S. A. 1992. Soybean mosaic potyvirus enhances the titer of two comoviruses in dually infected soybean plants. Phytopathology 82:1022-1027.

2. Bowers, G. R., Jr., and Goodman, R. M. 1979. Soybean mosaic virus: Infection of soybean seed parts and seed transmission. Phytopathology 69:569-572.

3. Calvert, L. A., and Ghabrial, S. A. 1983. Enhancement by soybean mosaic virus of bean pod mottle virus titer on doubly infected soybean. Phytopathology 73:992-997.

4. Canning, E. S. G., Penrose, M. J., Barker, I., and Coates, D. 1996. Improved detection of barley yellow dwarf virus in single aphids using RT-PCR. J. Virol. Methods 56:191-197.

5. Cho, E.-K., and Goodman, R. M. 1979. Strains of soybean mosaic virus: Classification based on virulence in resistant soybean cultivars. Phytopathology 69:467-470.

6. Damsteegt, V. D., Stone, A. L., and Hewings, A. D. 1995. Soybean dwarf, bean leaf roll, and beet western yellows luteoviruses in southeastern U.S. white clover. Plant Dis. 79:48-50.
7. Eastop, V. F. 1977. Worldwide importance of aphids as virus vectors. Pages 1-62 in: Aphids as Virus Vectors. K. F. Harris and K. Maramorosch, eds. Academic Press, New York.

8. Fehr, W. R., Caviness, C. E., Burmood, D. T., and Pennington, J. S. 1971. Stages of development descriptions for soybeans, Glycine $\max ($ L.) Merr. Crop Sci. 11:929-931.

9. Galvez, G. E. 1963. Host-range, purification, and electron microscopy of soybean mosaic virus. Phytopathology 53:388-393.

10. Gu, H., Clark, A. J., de Sa, P. B., Pfeiffer, T. W., and Ghabrial, S. A. 2002. Genetic diversity among isolates of Bean pod mottle virus. Phytopathology 92:446-452.

11. Hadidi, A., Montasser, M. S., Levy, L., Goth, R. W., Converse, R. H., Madkour, M. A., and Skrzeckowski, L. J. 1993. Detection of potato leafroll and strawberry mild yellow-edge luteoviruses by reverse transcriptionpolymerase chain reaction amplification. Plant Dis. 77:595-601.

12. Halbert, S. E., Irwin, M. E., and Goodman, R. M. 1981. Alate aphid (Homoptera: Aphididae) species and their relative importance as field vectors of soybean mosaic virus. Ann. Appl. Biol. 97:1-9.

13. Henson, L. M., and French, R. 1993. The polymerase chain reaction and plant disease diagnosis. Annu. Rev. Phytopathol. 31:81109.

14. Hill, J. H., Alleman, R., and Hogg, D. B. 2001. First report of transmission of Soybean mosaic virus and Alfalfa mosaic virus by Aphis glycines in the New World. Plant Dis.85:561.

15. Hill, J. H., Lucas, B. S., Benner, H. I., Tachibana, H., Hammond, R. B., and Pedigo, L. P. 1980. Factors associated with the epidemiology of soybean mosaic virus in Iowa. Phytopathology 70:536-540.

16. Irwin, M. E., and Goodman, R. M. 1981. Ecology and control of soybean mosaic virus. Pages 181-200 in: Plant Diseases and Vectors: Ecology and Epidemiology. K. Maramorosch and K. F. Harris, eds. Academic Press, New York.

17. Irwin, M. E., Ruesink, W. G., Isard, S. A., and Kampmeier, G. E. 2000. Mitigating epidemics caused by non-persistently transmitted aphidborne viruses: The role of the pliant environment. Virus Res. 71:185-211.

18. Iwaki, M., Roechan, M., Hibino, H., Tochihara, H., and Tantera, D. M. 1980. A persistent aphidborne virus of soybean, Indonesian soybean dwarf virus. Plant Dis. 64:10271030.

19. Lopez-Moya, J. J., Cubero, J., Lopez-Abella, D., and Diaz-Ruiz, J. R. 1992. Detection of cauliflower mosaic virus (CaMV) in single aphids by the polymerase chain reaction (PCR). J. Virol. Methods 37:129-138.

20. Lu, L. H., and Chen, R. L. 1993. Study on the production of alatae in soybean aphid, Aphis glycines. Acta Entomol. Sin. 36:143-149.

21. Martin, B., Collar, J. L., Tjallingii, W. F., and Fereres, A. 1997. Intracellular ingestion and salivation by aphids may cause the acquisition and inoculation of non-persistently transmitted plant viruses. J. Gen. Virol. 78:2701-2705.

22. Naidu, R. A., Robinson, D. J., and Kimmins, F. M. 1998. Detection of each of the causal agents of groundnut rosette disease in plants and vector aphids by RT-PCR. J. Virol. Methods 76:9-18.

23. Pirone, T. P., and Harris, K. F. 1977. Nonpersistent transmission of plant viruses by aphids. Annu. Rev. Phytopathol. 15:55-73.

24. Pirone, T. P., and Thornbury, D. W. 1988. Quantity of virus required for aphid transmission of a potyvirus. Phytopathology 78:104-107.
25. Raccah, B., and Pirone, T. P. 1984. Characteristics of and factors affecting helpercomponent-mediated aphid transmission of a potyvirus. Phytopathology 74:305-308.

26. Ross, J. P. 1968. Effect of single and double infections of soybean mosaic and bean pod mottle viruses on soybean yield and seed characters. Plant Dis. Rep. 52:344-348.

27. Ruesink, W. G., and Irwin, M. E. 1986. Soybean mosaic virus epidemiology: A model and some implications. Pages 295-313 in: Plant Virus Epidemics: Monitoring, Modelling and Predicting Outbreaks. G. D. McLean, R. G. Garrett, and W. G. Ruesink, eds. Academic Press, New York.

28. Schultz, G. A., Irwin, M. E., and Goodman, R. M. 1983. Factors affecting aphid acquisition and transmission of soybean mosaic virus. Ann. Appl. Biol. 103:87-96.

29. Schultz, G. A., Irwin, M. E., and Goodman, R. M. 1985. Relationship of aphid (Homoptera: Aphididae) landing rates to the field spread of soybean mosaic virus. J. Econ. Entomol. 78:143-147.

30. Singh, R. P. 1998. Reverse-transcription polymerase chain reaction for the detection of viruses from plants and aphids. J. Virol. Methods 74:125-138.

31. Singh, R. P. 1999. A solvent-free, rapid and simple virus RNA-release method for potato leafroll virus detection in aphids and plants by reverse transcription polymerase chain reaction. J. Virol. Methods 83:27-33.

32. Singh, R. P., Kurz, J., and Boiteau, G. 1996. Detection of stylet-borne and circulative potato viruses in aphids by duplex reverse transcription polymerase chain reaction. J. Virol Methods 59:189-196.

33. Singh, R. P., Kurz, J., Boiteau, G., and Gernard, G. 1995. Detection of potato leafroll virus in single aphids by the reverse transcription polymerase chain reaction and its potential epidemiological application. J. Virol. Methods 55:133-143.

34. Singh, R. P., Kurz, J., Boiteau, G., and Moore, L. M. 1997. Potato leafroll virus detection by RT-PCR in field-collected aphids. Am. Potato J. 74:305-313.

35. Stevens, M., Hull, R., and Smith, H. G. 1997. Comparison of ELISA and RT-PCR for the detection of beet yellows closterovirus in plants and aphids. J. Virol. Methods 68:9-16.

36. Swenson, K. G. 1968. Role of aphids in the ecology of plant viruses. Annu. Rev. Phytopathol. 6:351-374.

37. Takahashi, S., Inaizumi, M., and Kawakami, K. 1993. Life cycle of the soybean (Glycine max) aphid Aphis glycines Matsumura, in Japan. Jpn. J. Appl. Entomol. Zool. 37:207212 .

38. Wang, R. Y., Ammar, E. D., Thornbury, D. W., Lopez-Moya, J. J., and Pirone, T. P. 1996. Loss of potyvirus transmissibility and helpercomponent activity correlate with nonretention of virions in aphid stylets. J. Gen. Virol. 77:861-867.

39. Wang, S. Y., Bao, X. Z., Sun, Y. J., Chen, R. L., and Zhai, B. P. 1996. Study on the effects of the population dynamics of soybean aphid (Aphis glycines) on both growth and yield of soybean. Soybean Sci. 15:243-247.

40. Zhang, G. X., Zhong, T. S., and Chang, G. S. 1982. Experimental studies on some aphid life-cycle patterns. Sinozoologica 2:7-17.

41. Zhang, M. H., Lu, W. Q., Zhong, Z. X., Wang, R. Y., and Li, Y. H. 1986. The importance of the diseased seedlings from SMV infected seeds and the vector of the virus in the epidemic. Acta Phytopathol. Sin. 16:151-158.

42. Zitter, T. A. 1977. Epidemiology of aphidborne viruses. Pages 385-412 in: Aphids as Virus Vectors. K. F. Harris and K. Maramorosch, eds. Academic Press, New York. 